\title{
Sex ratios at birth after induced abortion
}

\author{
Marcelo L. Urquia PhD, Rahim Moineddin PhD, Prabhat Jha MD DPhil, Patricia J. O'Campo PhD, \\ Kwame McKenzie MD, Richard H. Glazier MD MPH, David A. Henry MD, Joel G. Ray MD MSc
}

See also www.cmaj.ca/lookup/doi/10.1503/cmaj.160183 and CMAJ Open article www.cmajopen.ca/content/4/2/E116

\begin{abstract}
Background: Skewed male:female ratios at birth have been observed among certain immigrant groups. Data on abortion practices that might help to explain these findings are lacking.

Methods: We examined 1220933 births to women with up to 3 consecutive singleton live births between 1993 and 2012 in Ontario. Records of live births, and induced and spontaneous abortions were linked to Canadian immigration records. We determined associations of male:female infant ratios with maternal birthplace, sex of the previous living sibling(s) and prior spontaneous or induced abortions.
\end{abstract}

Results: Male:female infant ratios did not appreciably depart from the normal range among Canadian-born women and most women born outside of Canada, irrespective of the sex of previous children or the characteristics of prior abortions. However, among infants of women who immigrated from India and had previously given birth to 2 girls, the overall male:female ratio was 1.96 (95\% confidence interval $[\mathrm{Cl}]$ 1.75-2.21) for the third live birth. The male:female infant ratio after 2 girls was $1.77(95 \% \mathrm{Cl} 1.26-2.47)$ times higher if the current birth was preceded by 1 induced abortion, 2.38 (95\% Cl 1.44-3.94) times higher if preceded by 2 or more induced abortions and 3.88 (95\% Cl 2.02-7.50) times higher if the induced abortion was performed at 15 weeks or more gestation relative to no preceding abortion. Spontaneous abortions were not associated with male-biased sex ratios in subsequent births.

Interpretation: High male:female ratios observed among infants born to women who immigrated from India are associated with induced abortions, especially in the second trimester of pregnancy.
$\mathrm{T}$ he natural odds of having a male child — the male:female ratio at birth — is relatively stable across human populations. ${ }^{1,2}$ It ranges between 1.03 and 1.07 males per female, and is largely independent of birth order and the sex of previous siblings. ${ }^{2,3}$ Modest variations in the natural male:female ratio have been linked to demographic, biologic and environmental factors, ${ }^{2,4-6}$ including wartime and environmental disasters. ${ }^{7-9}$

In certain Asian countries, a higher-thanexpected male:female ratio at birth is thought to be a product of sex discrimination fuelled by the preference for sons. This preference has been attributed to various economic and cultural factors, including provision of financial support in old age, the burden of dowry payments and worship duties in India, ${ }^{10,11}$ patrilineal lineage in China and India, and the 1-child policy in China. ${ }^{10}$ One major mechanism behind skewed male:female infant ratios is thought to be induced abortion of female fetuses identified on early prenatal ultrasonog- raphy, particularly among couples with 2 prior daughters. Differing male:female infant ratios may also be explained by differential use of pre- and postfertilization techniques, ${ }^{12}$ bias in the reporting of live births ${ }^{13}$ and sex-selective postnatal infanticide. ${ }^{14}$ The body of literature to date reflects mostly indirect evidence obtained by rough measurement of male:female ratios at birth in India, ${ }^{15-17}$ China, ${ }^{13,18,19}$ Vietnam $^{20,21}$ and the rest of Asia. ${ }^{22-25}$ Prior studies of this phenomenon in industrialized countries have looked at maternal country of origin broadly but have observed it predominantly among Asian immigrants from countries where malebiased infant sex ratios have been extensively documented. ${ }^{10,26-30}$ Data on the relation between abortion practices and male:female infant ratios are lacking.

Although prenatal sex selection is thought to occur within certain Asian countries (e.g., India), ${ }^{31}$ differing approaches to interpretation of sex ratios at birth has led to some controversy regarding its practice in North America
Competing interests: None declared.

This article has been peer reviewed.

Accepted: Jan. 8, 2016

Online: Apr. 11, 2016

Correspondence to:

Marcelo Urquia,

urquiam@smh.ca

CMAJ 2016. DOI:10.1503/ cmaj.151074 
and the United Kingdom. ${ }^{32-34}$ Published studies rarely considered the sex of the previous siblings - a key determinant of subsequent fertility decisions ${ }^{35}$ - nor did they distinguish between women who had induced abortions following live births from those who had not.

We studied the male:female ratios of liveborn children in Ontario, where induced abortions are both legal and free. Our objective was to evaluate the male:female ratio at birth in relation to the mother's country of birth, the sex and birth order of her children, and the type, number and timing of any abortions she had between live births.

\section{Methods}

\section{Study setting and participants}

The eligible study population comprised all singleton live births to women residing in Ontario at the time of delivery who had a valid Ontario health card number. The study sample was retrieved from population-based administrative databases linked at the Institute for Clinical Evaluative Sciences (Toronto) and restricted to women who had up to 3 consecutive singleton live births in Ontario hospitals starting Apr. 1, 1993, of which at least 1 live birth occurred between Apr. 1, 2002, and Mar. 31, 2012. The latter is required because all previous live births would have been reported in the obstetrical delivery record since Apr. 1, 2002, and this number had to agree with the historical count of liveborn deliveries to the same mother to accurately measure live-birth order. If the 2 numbers differed, we excluded these women and all of their births to avoid including women with incomplete reproductive history. We also excluded births for which sex of the infant was unknown, fourth- or higher-order live births that resulted in sparse data, women whose first birth was before April 1993 and women whose country of birth could not be determined.

\section{Variable definitions and data sources}

We defined birth order as the complete sequence of up to 3 consecutive live births from the same mother. We updated birth order at each subsequent live birth by removing prior siblings who were no longer alive by the estimated conception date of the current live birth, based on the assumption that fertility decisions are based on the number and sex of the children currently alive. Alive status was assessed via a linkage with the death database of the Ontario Office of the Registrar General, complemented by in-hospital deaths.

We ascertained maternal birthplace through the Citizenship and Immigration Canada permanent resident database, which has the immigra- tion records of all individuals granted permanent residency in Canada since January 1985. The immigration database is linked with the Ontario Registered Persons Database, a registry that contains the unique health numbers that have been issued to individuals eligible for coverage under the Ontario Health Insurance Plan (OHIP). About $90 \%$ of individuals in the immigration database were matched to a resident of Ontario with a valid health card number. Unmatched immigrants may have moved out of Ontario or may have been misclassified as nonimmigrants. Sociodemographic characteristics did not significantly differ between matched and unmatched individuals, suggesting little, if any, selection bias among immigrants. ${ }^{36} \mathrm{We}$ assigned 6 groups by maternal birthplace: born in Canada (group contains a small proportion of immigrant residents who could not be matched to the immigration registry or who immigrated before 1985), immigrants from India, immigrants from China (including Hong Kong, Macau and Taiwan), immigrants from other South Asian countries (Afghanistan, Bangladesh, Sri Lanka, Pakistan), immigrants from other Asian countries (Iran, Nepal, Bhutan, Maldives, Vietnam, Philippines, Indonesia, Cambodia, Thailand, Singapore, Myanmar, Lao People's Democratic Republic, Brunei Darussalam, Timor-Leste and Malaysia) and immigrants from the rest of the world.

We defined induced abortions as any surgical or medication-induced termination of pregnancy. If 2 consecutive abortions were recorded within 40 days of each other, they were considered the same event, and the date of the first abortion was used. Induced abortions performed in a hospital acute care, day surgery or emergency department setting were captured in the Discharge Abstracts Database, Same-DaySurgery Database and the National Ambulatory Care Reporting System of the Canadian Institute for Health Information, under mandatory reporting requirements. To be considered an induced abortion, a record must have had a procedure code for a termination of pregnancy without a concomitant diagnostic code for a spontaneous abortion (Appendix 1, available at www.cmaj.ca/lookup/suppl/doi:10.1503/ cmaj.151074/-/DC1). Abortions performed out of hospital were captured using the OHIP physician billing codes for a surgical induced abortion. An induced abortion was classified according to whether it was performed at less than 15 weeks or at 15 weeks or more gestation, based on fee codes S752 and S785, respectively. Terminations at 15 weeks or more are only eligible for payment if gestational age is confirmed by ultrasonography. 


\section{Statistical analysis}

The male:female ratio is a particular example of the odds $\left[P_{\text {male }} /\left(1-P_{\text {male }}\right)\right]$, expressed herein as the proportion of males divided by the proportion of females, at the current (index) delivery. Therefore, to calculate male:female infant ratios (i.e., the odds of a liveborn child being male rather than female) we used intercept-only logistic regression models, with $95 \%$ confidence intervals (CIs), within each stratum of maternal birthplace and sex of the previous sibling(s). We also used logistic regression to assess if male:female ratios in the current birth differed according to the type of abortion (none [referent], spontaneous, induced), an increasing number of induced abortions (none [referent], one, 2 or more) and the timing of abortions (none [referent], < 15 weeks gestation, $\geq 15$ weeks gestation) performed during the interval between the previous and current (index) liveborn child. For these models, we calculated odds ratios (ORs) (i.e., the ratio of 2 odds or 2 male:female ratios). To account for small cell sizes at the third live birth, we used exact methods. To test for trend, the number and timing of abortions were also entered as a linear term in the models.

In models restricted to women born in Canada, we adjusted for maternal age and neighbourhood income quintiles. In models restricted to immigrants, we further adjusted for maternal education at arrival, marital status at arrival and duration of residence in Canada, because these characteristics were only available in the immigration registry. For analyses assessing differences in length of interval between the second and third live birth, we adjusted for the number of spontaneous abortions within that time interval. We analyzed the data using SAS version 9.3 (SAS Institute).

The study was approved by the St. Michael's Hospital and Sunnybrook Health Sciences Centre Research Ethics Board (Toronto).

\section{Results}

There were 1310881 live births to women with a complete reproductive history. We sequentially excluded 27171 births without known infant sex, 34567 fourth- or higher-order births, 18710 births to mothers whose first recorded birth in Ontario occurred before 1993 and 9500 births to women with unknown country of birth. The final study sample comprised 1220933 live births, including 153829 (12.6\%) to women who had immigrated from Asia.

As expected, the number of live births declined with increasing birth order among all groups, but it varied according to the sex of the previous sibling(s) (Table 1). Women who had immigrated from India and who gave birth to a third child were 2.9 times more likely to have previously given birth to 2 females rather than 2 males (1262 v. 439 newborns). Similarly, but to a less pronounced degree, women who immigrated from China and who had a third child were 1.5 times more likely to have 2 previous females than 2 males (396 v. 262 newborns). These differences were not seen among women from other countries or among women born in Canada. With the exception of women who immigrated from India, there were fewer third births among women who had 2 previous children of different sexes (Table 1).

For most groups, male:female infant ratios showed little variation according to maternal birthplace and sex of the previous sibling(s). The exception was among women who immigrated from India (male:female ratio at the third birth 1.96, 95\% CI 1.75 to 2.21 after 2 girls) (Table 1). The effect was most pronounced among women who immigrated from India with 2 previous girls followed by 1 or more induced abortions (male:female ratio 3.26 , 95\% CI 2.53 to 4.21 ), and less pronounced among those who did not have a recorded induced abortion after 2 girls (male:female ratio $1.68,95 \%$ CI 1.47 to 1.91 ). Other than in immigrants from India, further analyses did not reveal any association between male sex in the current birth and abortion history (Appendix 2, available at www.cmaj.ca/lookup/ suppl/doi:10.1503/cmaj.151074/-/DC1). Therefore, the analyses that follow were limited to a comparison of women born in India and women born in Canada.

The male:female ratio for the third live birth was 1.91 (95\% CI 1.42 to 2.57) times higher following 1 or more induced abortions after the birth of 2 females among women born in India compared with those who did not undergo an induced abortion between the second and third birth (Figure 1). However, having had a spontaneous abortion since the previous live birth was not significantly associated with male sex of the current live birth, at any level of birth order or sex of the previous sibling(s).

The male:female ratio for the third live birth showed a dose-response relation among women born in India, by the number of induced abortions performed after the birth of 2 girls ( $p$ [for trend] $<0.001$ ) and the birth of 2 boys $(p$ for trend $]=0.03)$ (Figure 2$)$.

Among women born in India, we also found a dose-response relation between male sex and the timing of the induced abortion after having 1 girl ( $p$ [for trend] $=0.04$ ) and after having 2 girls ( $p$ [for 
trend] < 0.001) (Figure 3). For all third births, compared with those not preceded by an induced abortion, the male:female ratio was 1.62 (95\% CI 1.18 to 2.22 ) times higher if preceded by at least 1 abortion before 15 weeks gestation and 3.88 (95\% CI 2.02 to 7.50 ) times higher if preceded by 1 or more

Table 1: Male and female live births in Ontario, 1993-2012, by maternal birthplace and by sex of previous live born sibling(s)

\begin{tabular}{|c|c|c|c|c|}
\hline \multirow{2}{*}{$\begin{array}{l}\text { Maternal } \\
\text { birthplace; } \\
\text { birth order }\end{array}$} & \multirow[b]{2}{*}{$\begin{array}{l}\text { Sex of previous } \\
\text { sibling(s) }\end{array}$} & \multicolumn{3}{|c|}{ All live births } \\
\hline & & No. of live births & $\begin{array}{l}\text { No. of males/ } \\
\text { females }\end{array}$ & $\begin{array}{c}\text { Male:female ratio } \\
(95 \% \mathrm{Cl})\end{array}$ \\
\hline \multicolumn{5}{|l|}{ Canada } \\
\hline 1 & - & 540552 & $276697 / 263855$ & 1.05 (1.04 to 1.05$)$ \\
\hline \multirow[t]{2}{*}{2} & $M$ & 166438 & 86 069/80 369 & 1.07 (1.06 to 1.08$)$ \\
\hline & $\mathrm{F}$ & 158120 & 80 376/77 744 & 1.03 (1.02 to 1.04$)$ \\
\hline \multirow[t]{3}{*}{3} & $\mathrm{MM}$ & 26717 & $13824 / 12893$ & $1.07(1.05$ to 1.10$)$ \\
\hline & $\mathrm{FF}$ & 23749 & $12089 / 11660$ & 1.04 (1.01 to 1.06$)$ \\
\hline & MF or FM* & 40223 & $20718 / 19505$ & $1.06(1.04$ to 1.08$)$ \\
\hline \multicolumn{5}{|l|}{ India } \\
\hline 1 & - & 24170 & $12134 / 12036$ & 1.01 (0.98 to 1.03$)$ \\
\hline \multirow[t]{2}{*}{2} & $M$ & 6491 & $3390 / 3101$ & 1.09 (1.04 to 1.15$)$ \\
\hline & $\mathrm{F}$ & 7012 & $3635 / 3377$ & 1.08 (1.03 to 1.13$)$ \\
\hline \multirow[t]{3}{*}{3} & MM & 439 & $227 / 212$ & 1.07 (0.89 to 1.29$)$ \\
\hline & $\mathrm{FF}$ & 1262 & $836 / 426$ & 1.96 (1.75 to 2.21$)$ \\
\hline & MF or FM* & 1002 & $541 / 461$ & $1.17(1.04$ to 1.33$)$ \\
\hline \multicolumn{5}{|l|}{ China } \\
\hline 1 & - & 19694 & $10173 / 9521$ & $1.07(1.04$ to 1.10$)$ \\
\hline \multirow[t]{2}{*}{2} & $M$ & 4335 & $2237 / 2098$ & 1.07 (1.01 to 1.13$)$ \\
\hline & $\mathrm{F}$ & 4244 & $2200 / 2044$ & 1.08 (1.01 to 1.14$)$ \\
\hline \multirow[t]{3}{*}{3} & MM & 262 & $128 / 134$ & $0.96(0.75$ to 1.22$)$ \\
\hline & $\mathrm{FF}$ & 396 & $199 / 197$ & 1.01 (0.83 to 1.23$)$ \\
\hline & MF or FM* & 385 & $201 / 184$ & 1.09 (0.89 to 1.33$)$ \\
\hline \multicolumn{5}{|c|}{ Other South Asian countries } \\
\hline 1 & - & 27475 & $13948 / 13527$ & $1.03(1.01$ to 1.06$)$ \\
\hline \multirow[t]{2}{*}{2} & $\mathrm{M}$ & 8333 & $4208 / 4125$ & $1.02(0.98$ to 1.07$)$ \\
\hline & $\mathrm{F}$ & 8220 & $4073 / 4147$ & 0.98 (0.94 to 1.03$)$ \\
\hline \multirow[t]{3}{*}{3} & MM & 1324 & $670 / 654$ & $1.02(0.92$ to 1.14$)$ \\
\hline & $\mathrm{FF}$ & 1448 & $713 / 735$ & 0.97 (0.88 to 1.08$)$ \\
\hline & MF or FM* & 2372 & $1200 / 1172$ & $1.02(0.95$ to 1.11$)$ \\
\hline \multicolumn{5}{|c|}{ Other Asian countries } \\
\hline 1 & - & 21564 & 11 119/10 445 & 1.07 (1.04 to 1.09$)$ \\
\hline \multirow[t]{2}{*}{2} & $\mathrm{M}$ & 5592 & $2968 / 2624$ & $1.13(1.07$ to 1.19$)$ \\
\hline & $\mathrm{F}$ & 5354 & $2733 / 2621$ & $1.04(0.99$ to 1.10$)$ \\
\hline \multirow[t]{3}{*}{3} & $\mathrm{MM}$ & 725 & $352 / 373$ & $0.94(0.82$ to 1.09$)$ \\
\hline & $\mathrm{FF}$ & 716 & $375 / 341$ & $1.10(0.95$ to 1.27$)$ \\
\hline & MF or FM* & 1014 & $526 / 488$ & $1.08(0.95$ to 1.22$)$ \\
\hline \multicolumn{5}{|c|}{ Rest of the world } \\
\hline 1 & - & 65046 & 33 340/31 706 & 1.05 (1.04 to 1.07$)$ \\
\hline \multirow[t]{2}{*}{2} & $M$ & 18193 & $9328 / 8865$ & $1.05(1.02$ to 1.08$)$ \\
\hline & $\mathrm{F}$ & 17440 & $8937 / 8503$ & 1.05 (1.02 to 1.08$)$ \\
\hline \multirow[t]{3}{*}{3} & $\mathrm{MM}$ & 2899 & $1487 / 1412$ & 1.05 (0.98 to 1.13$)$ \\
\hline & $\mathrm{FF}$ & 2801 & $1411 / 1390$ & 1.02 (0.94 to 1.09$)$ \\
\hline & MF or FM* & 4926 & $2508 / 2418$ & $1.04(0.98$ to 1.10$)$ \\
\hline Total & & 1220933 & 625 570/595 363 & 1.05 (1.05 to 1.05$)$ \\
\hline
\end{tabular}


abortions at 15 weeks or more gestation. After giving birth to 2 males, an induced abortion at 15 weeks or more gestation among women born in India was so uncommon that data suppression was required because of the small counts (Figure 3).

We found the longest interval between the birth of a second and third child among women born in India, particularly those who had previously given birth to 2 girls. Among the latter, the birth interval was 3.8 (95\% CI 0.9 to 6.7) months longer if the third live birth was a male (mean interval $=49.0 \mathrm{mo}$ ) rather than a female (mean interval $=45.4 \mathrm{mo}$ ), after we adjusted for the number of spontaneous abortions (Table 2).

\section{Mothers born in Canada}

\begin{tabular}{|c|c|c|c|c|}
\hline $\begin{array}{l}\text { Sex of prior } \\
\text { sibling(s) }\end{array}$ & Abortion type & $\begin{array}{l}\text { No. of males/females } \\
\text { (male:female ratio) }\end{array}$ & $\begin{array}{l}\text { Crude OR } \\
(95 \% \mathrm{Cl})\end{array}$ & $\begin{array}{l}\text { Adjusted OR* } \\
\qquad(95 \% \mathrm{Cl})\end{array}$ \\
\hline \multirow[t]{3}{*}{ M } & None & $74371 / 69119$ (1.08) & 1.00 & 1.00 \\
\hline & Spontaneous & $5907 / 5671(1.04)$ & $0.97(0.93$ to 1.01$)$ & 0.97 (0.93 to 1.01$)$ \\
\hline & Induced & $5791 / 5579$ (1.04) & $0.97(0.93$ to 1.00$)$ & 0.96 (0.93 to 1.00$)$ \\
\hline \multirow[t]{3}{*}{$\mathrm{F}$} & None & 69207/66821 (1.04) & 1.00 & 1.00 \\
\hline & Spontaneous & $5698 / 5522(1.03)$ & 1.00 (0.96 to 1.04$)$ & 1.00 (0.96 to 1.04$)$ \\
\hline & Induced & $5471 / 5401(1.01)$ & $0.98(0.94$ to 1.02$)$ & $0.98(0.94$ to 1.02$)$ \\
\hline \multirow[t]{3}{*}{ MM } & None & $12014 / 11144(1.08)$ & 1.00 & 1.00 \\
\hline & Spontaneous & $892 / 832$ (1.07) & $0.99(0.90$ to 1.10$)$ & $1.00(0.90$ to 1.10$)$ \\
\hline & Induced & $918 / 917(1.00)$ & $0.93(0.84$ to 1.02$)$ & 0.93 (0.85 to 1.03$)$ \\
\hline \multirow[t]{3}{*}{ FF } & None & $10432 / 10087$ (1.03) & 1.00 & 1.00 \\
\hline & Spontaneous & $764 / 740(1.03)$ & $1(0.90$ to 1.11$)$ & $1.00(0.90$ to 1.11$)$ \\
\hline & Induced & $893 / 833$ (1.07) & 1.04 (0.94 to 1.14$)$ & 1.04 (0.94 to 1.15$)$ \\
\hline \multirow[t]{3}{*}{ MF, FM } & None & $17800 / 16608(1.07)$ & 1.00 & 1.00 \\
\hline & Spontaneous & $1184 / 1186(1.00)$ & $0.93(0.86$ to 1.01$)$ & $0.93(0.86$ to 1.01$)$ \\
\hline & Induced & $1734 / 1711(1.01)$ & $0.95(0.88$ to 1.01$)$ & 0.95 (0.88 to 1.02$)$ \\
\hline
\end{tabular}

\section{Mothers born in India}

$\begin{array}{llc}\begin{array}{l}\text { Sex of prior } \\ \text { sibling(s) }\end{array} & \text { Abortion type } & \begin{array}{c}\text { No. of males/females } \\ \text { (male:female ratio) }\end{array} \\ \text { M } & \text { None } & 2667 / 2452(1.08) \\ & \text { Spontaneous } & 191 / 155(1.23) \\ \text { F } & \text { Induced } & 532 / 494(1.07) \\ & \text { None } & 2822 / 2647(1.06) \\ \text { MM } & \text { Spontaneous } & 203 / 206(0.98) \\ & \text { Induced } & 610 / 524(1.16) \\ & \text { None } & 169 / 169(1.00) \\ \text { FF } & \text { Spontaneous } & 6 / 11(0.55) \\ & \text { Induced } & 52 / 32(1.63) \\ & \text { None } & 544 / 321(1.69) \\ & \text { Spontaneous } & 41 / 28(1.46) \\ \text { MF, FM } & \text { Induced } & 251 / 77(3.26) \\ & \text { None } & 409 / 356(1.15) \\ & \text { Spontaneous } & 21 / 21(1.00) \\ & \text { Induced } & 111 / 84(1.32)\end{array}$

\begin{tabular}{ll}
\multicolumn{1}{c}{$\begin{array}{c}\text { Crude } \text { OR } \\
(95 \% \mathrm{Cl})\end{array}$} & \multicolumn{1}{c}{$\begin{array}{c}\text { Adjusted } \mathrm{OR}^{*} \boldsymbol{t} \\
(95 \% \mathrm{Cl})\end{array}$} \\
1.00 & 1.00 \\
$1.13(0.91$ to 1.41$)$ & $1.13(0.91$ to 1.41$)$ \\
$0.99(0.86$ to 1.13$)$ & $0.99(0.86$ to 1.13$)$ \\
1.00 & 1.00 \\
$0.92(0.75$ to 1.13$)$ & 0.89 (0.73 to 1.09$)$ \\
$1.09(0.96$ to 1.24$)$ & $1.08(0.95$ to 1.23$)$ \\
1.00 & 1.00 \\
$0.55(0.19$ to 1.50$)$ & $0.60(0.21$ to 1.70$)$ \\
$1.63(1.00$ to 2.65$)$ & $1.58(0.96$ to 2.61$)$ \\
1.00 & 1.00 \\
$0.86(0.52$ to 1.42$)$ & $0.85(0.51$ to 1.40$)$ \\
$1.92(1.43$ to 2.57$)$ & $1.91(1.42$ to 2.57$)$ \\
1.00 & 1.00 \\
$0.87(0.47$ to 1.62$)$ & $0.87(0.46$ to 1.62$)$ \\
$1.15(0.84$ to 1.58$)$ & $1.20(0.87$ to 1.66$)$
\end{tabular}

Females more Males more $\longleftarrow$ likely likely $\longrightarrow$

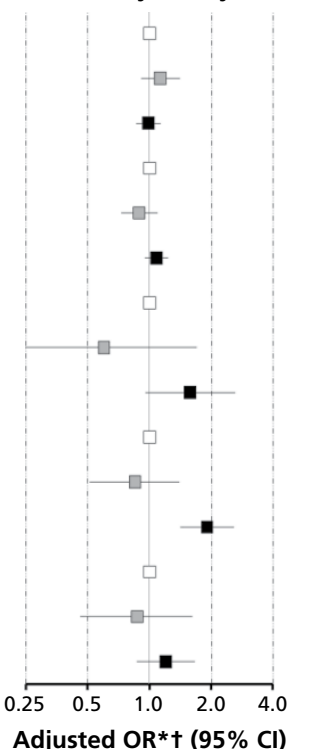

Figure 1: Crude and adjusted odds ratios (ORs) for giving birth to a male liveborn infant (index birth) among women who had at least 1 recorded spontaneous or induced abortion between the preceding live birth and the index birth compared with women who had no abortion during the same birth interval, from 1993 to 2012, by maternal place of birth and stratified by sex of previous living sibling(s). Values greater than 1.0 indicate an increased likelihood of having a male infant. *Adjusted for maternal age and neighbourhood income quintile. tAlso adjusted for maternal education and marital status at arrival, and duration of residence in $\mathrm{Canada}$. $\mathrm{Cl}=\mathrm{confi}-$ dence interval, $\mathrm{FF}=$ both prior living siblings were female, $\mathrm{MM}=$ both prior living siblings were male. 


\section{Interpretation}

Our findings show that, among some immigrants from India, prior induced abortion is associated with subsequently giving birth to a boy, especially at the third birth and among women who had given birth to 2 previous girls.
Our findings also provide details about specific factors associated with this practice. First, preference for sons can be inferred by the fact that the number of third-order births, irrespective of sex, was 3 times more common among mothers born in India who had 2 previous girls than among mothers born in India with 2 previous

\section{Mothers born in Canada}

$\begin{array}{lcl}\begin{array}{l}\text { Sex of prior } \\ \text { sibling(s) }\end{array} & \begin{array}{c}\text { No. of } \\ \text { abortions }\end{array} & \begin{array}{c}\text { No. of males/females } \\ \text { (male:female ratio) }\end{array} \\ \text { M } & 0 & \begin{array}{l}80278 / 74790(1.07) \\ 4132 / 3975(1.04)\end{array} \\ & 1 & 1659 / 1604(1.03) \\ \text { F } & \geq 2 & 74905 / 72343(1.04) \\ & 0 & 3840 / 3858(1.00) \\ \text { MM } & 1 & 1631 / 1543(1.06) \\ & \geq 2 & 12906 / 11976(1.08) \\ \text { FF } & 0 & 676 / 668(1.01) \\ & 1 & 242 / 249(0.97) \\ & \geq 2 & 11196 / 10827(1.03) \\ & 0 & 629 / 593(1.06) \\ \text { MF, FM } & 1 & 264 / 240(1.10) \\ & \geq 2 & 18984 / 17794(1.07) \\ & 0 & 1204 / 1155(1.04) \\ & 1 & 530 / 556(0.95)\end{array}$

\begin{tabular}{|c|c|}
\hline $\begin{array}{l}\text { Crude OR } \\
(95 \% \mathrm{Cl})\end{array}$ & $\begin{array}{l}\text { Adjusted OR* } \\
(95 \% \mathrm{Cl})\end{array}$ \\
\hline 1.00 & 1.00 \\
\hline 0.97 (0.93 to 1.01$)$ & 0.97 (0.93 to 1.01$)$ \\
\hline 0.96 (0.90 to 1.03$)$ & 0.96 (0.90 to 1.03$)$ \\
\hline 1.00 & 1.00 \\
\hline $0.96(0.92$ to 1.01$)$ & 0.97 (0.92 to 1.01$)$ \\
\hline $1.02(0.95$ to 1.10$)$ & 1.02 (0.95 to 1.10$)$ \\
\hline 1.00 & 1.00 \\
\hline 0.94 (0.84 to 1.05$)$ & 0.94 (0.85 to 1.05$)$ \\
\hline 0.90 (0.75 to 1.08$)$ & 0.91 (0.76 to 1.09$)$ \\
\hline 1.00 & 1.00 \\
\hline 1.03 (0.91 to 1.15$)$ & $1.03(0.92$ to 1.15$)$ \\
\hline $1.06(0.89$ to 1.27$)$ & 1.07 (0.89 to 1.28$)$ \\
\hline 1.00 & 1.00 \\
\hline 0.98 (0.90 to 1.06$)$ & 0.98 (0.90 to 1.07$)$ \\
\hline 0.89 (0.79 to 1.01$)$ & 0.90 (0.79 to 1.01$)$ \\
\hline
\end{tabular}

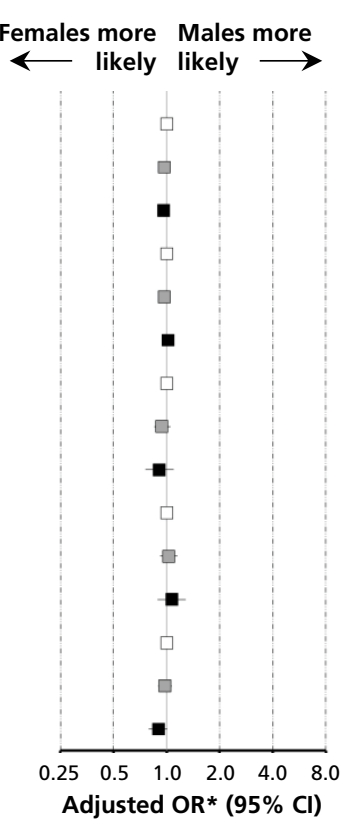

Mothers born in India

$\begin{array}{lll}\begin{array}{l}\text { Sex of prior } \\ \text { sibling(s) }\end{array} & \begin{array}{c}\text { No. of } \\ \text { abortions }\end{array} & \begin{array}{c}\text { No. of males/females } \\ \text { (male:female ratio) }\end{array} \\ \text { M } & 0 & 2858 / 2607(1.09) \\ & 1 & 420 / 392(1.07) \\ \text { F } & \geq 2 & 112 / 102(1.09) \\ & 0 & 3025 / 2853(1.06) \\ & 1 & 473 / 419(1.12) \\ \text { MM } & \geq 2 & 137 / 105(1.30) \\ & 0 & 175 / 180(0.97) \\ \text { FF } & 1 & 33 / 24(1.37) \\ & \geq 2 & 19 / 8(2.37) \\ & 0 & 585 / 349(1.67) \\ \text { MF, FM } & 1 & 165 / 56(2.94) \\ & \geq 2 & 86 / 21(4.09) \\ & 0 & 430 / 377(1.14) \\ & 1 & 70 / 67(1.04)\end{array}$

\begin{tabular}{ll}
\multicolumn{1}{c}{$\begin{array}{c}\text { Crude } \text { OR } \\
(95 \% \text { Cl })\end{array}$} & \multicolumn{1}{c}{$\begin{array}{c}\text { Adjusted } \mathrm{OR}^{*} \mathrm{~T} \\
(95 \% \mathrm{Cl})\end{array}$} \\
1.00 & 1.00 \\
$0.98(0.84$ to 1.13$)$ & $0.97(0.84$ to 1.13$)$ \\
$1.00(0.76$ to 1.32$)$ & 1.00 (0.76 to 1.31$)$ \\
1.00 & 1.00 \\
$1.07(0.93$ to 1.23$)$ & $1.06(0.92$ to 1.22$)$ \\
$1.23(0.95$ to 1.60$)$ & $1.21(0.93$ to 1.57$)$ \\
1.00 & 1.00 \\
$1.41(0.80$ to 2.49$)$ & $1.38(0.77$ to 2.45$)$ \\
$2.44(1.04$ to 5.72$)$ & $2.38(0.99$ to 5.74$)$ \\
1.00 & 1.00 \\
$1.76(1.26$ to 2.45$)$ & $1.77(1.26$ to 2.47$)$ \\
$2.44(1.49$ to 4.01$)$ & $2.38(1.44$ to 3.94$)$ \\
1.00 & 1.00 \\
$0.92(0.64$ to 1.32$)$ & $0.95(0.66$ to 1.37$)$ \\
$2.11(1.18$ to 3.78$)$ & $2.29(1.27$ to 4.15$)$
\end{tabular}

Females more Males more

$\longleftarrow$ likely likely $\longrightarrow$

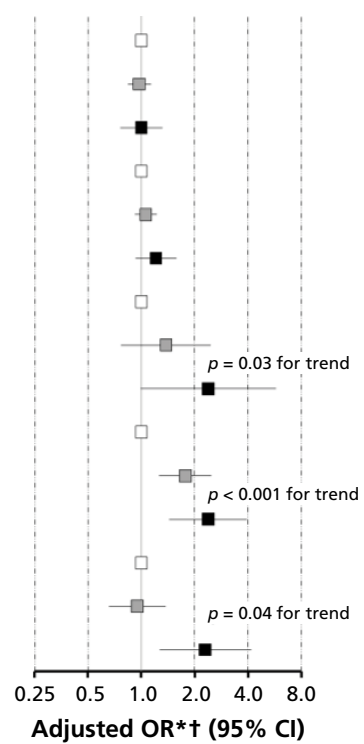

Figure 2: Crude and adjusted odds ratios (ORs) for giving birth to a male liveborn infant (index birth) among women who had 1, 2 or more induced abortions between the preceding live birth and the index birth, from 1993 to 2012, compared with women who had no abortion during the same birth interval, by maternal place of birth and stratified by sex of previous living sibling(s). Values greater than 1.0 indicate an increased likelihood of having a male infant. *Adjusted for maternal age and neighbourhood income quintile. tAlso adjusted for maternal education and marital status at arrival, and duration of residence in $\mathrm{Canada}$. $\mathrm{Cl}=\mathrm{confidence}$ interval, $\mathrm{FF}=$ both prior living siblings were female, $\mathrm{MM}$ = both prior living siblings were male. 
boys. Second, male:female infant ratios were also highest among women born in India with 2 previous daughters. Third, a third child was much more likely to be a boy after an induced abortion but not after a spontaneous abortion. The link with newborn male sex was stronger for births to women born in India who had 2 previous daughters, with a dose-response association observed by the number of induced abortions and the timing at which they were performed. The strongest indication was associated with abortions at 15 weeks or more gestation, most of which can be assumed to have been performed at a point in which the sex of the fetus

\section{Mothers born in Canada}

\begin{tabular}{|c|c|c|c|c|}
\hline $\begin{array}{l}\text { Sex of prior } \\
\text { sibling(s) }\end{array}$ & $\begin{array}{l}\text { Timing of } \\
\text { abortion }\end{array}$ & $\begin{array}{l}\text { No. of males/females } \\
\text { (male:female ratio) }\end{array}$ & $\begin{array}{l}\text { Crude OR } \\
(95 \% \mathrm{Cl})\end{array}$ & $\begin{array}{l}\text { Adjusted OR* } \\
(95 \% \mathrm{Cl})\end{array}$ \\
\hline \multirow[t]{3}{*}{ M } & None & $80278 / 74790$ (1.07) & 1.00 & 1.00 \\
\hline & $<15$ weeks & $5259 / 4993(1.05)$ & $0.98(0.94$ to 1.02$)$ & $0.98(0.94$ to 1.02$)$ \\
\hline & $\geq 15$ weeks & $532 / 586(0.91)$ & $0.85(0.75$ to 0.95$)$ & $0.85(0.75$ to 0.95$)$ \\
\hline \multirow[t]{3}{*}{$\mathrm{F}$} & None & $74905 / 72343$ (1.04) & 1.00 & 1.00 \\
\hline & $<15$ weeks & $4970 / 4896(1.02)$ & $0.98(0.94$ to 1.02$)$ & $0.98(0.94$ to 1.02$)$ \\
\hline & $\geq 15$ weeks & $501 / 505$ (0.99) & $0.96(0.85$ to 1.08$)$ & $0.96(0.85$ to 1.09$)$ \\
\hline \multirow[t]{3}{*}{ MM } & None & $12906 / 11976$ (1.08) & 1.00 & 1.00 \\
\hline & $<15$ weeks & $842 / 846(1.00)$ & $0.92(0.84$ to 1.02$)$ & $0.93(0.84$ to 1.03$)$ \\
\hline & $\geq 15$ weeks & $76 / 71(1.07)$ & $0.99(0.72$ to 1.37$)$ & $1.00(0.72$ to 1.38$)$ \\
\hline \multirow[t]{3}{*}{$\mathrm{FF}$} & None & $11196 / 10827$ (1.03) & 1.00 & 1.00 \\
\hline & $<15$ weeks & $803 / 756(1.06)$ & $1.03(0.93$ to 1.14$)$ & $1.03(0.93$ to 1.14$)$ \\
\hline & $\geq 15$ weeks & $90 / 77(1.17)$ & $1.13(0.83$ to 1.53$)$ & $1.13(0.83$ to 1.53$)$ \\
\hline \multirow[t]{3}{*}{ MF, FM } & None & $18984 / 17794$ (1.07) & 1.00 & 1.00 \\
\hline & $<15$ weeks & $1581 / 1536(1.03)$ & $0.97(0.90$ to 1.04$)$ & $0.97(0.90$ to 1.04$)$ \\
\hline & $\geq 15$ weeks & $153 / 175(0.87)$ & $0.82(0.66$ to 1.02$)$ & 0.82 (0.66 to 1.02$)$ \\
\hline
\end{tabular}

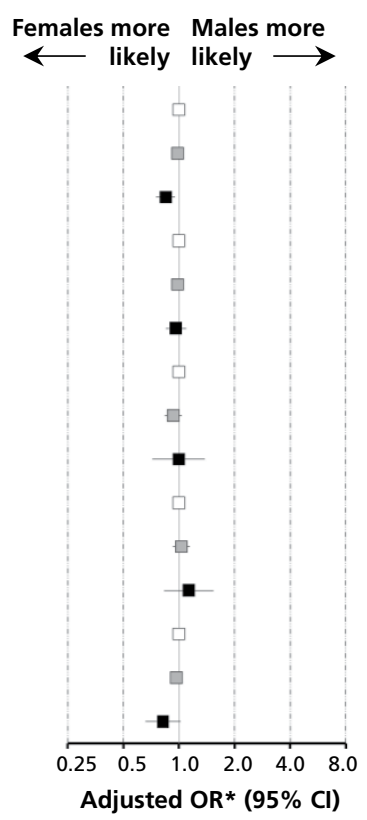

No. of males/females (male:female ratio)

Crude OR $(95 \% \mathrm{Cl})$ sibling(s)

Timing of abortion, wk M None

$<15$

$\geq 15$

F

None

$<15$

$\geq 15$

MM

None

$<15$

$\geq 15$

FF

None

$<15$

$\geq 15$

MF, FM
2858/2607 (1.09)

$513 / 481$ (1.06)

19/13 (1.46)

$3025 / 2853$ (1.05)

524/475 (1.10)

$86 / 49$ (1.75)

$175 / 180(0.97)$

‡

‡

585/349 (1.67)

178/66 (2.69)

73/11 (6.63)

430/377 (1.13)

105/78 (1.34)

$6 / 6(1.00)$
1.0

0.97 (0.85 to 1.11$)$

1.33 (0.66 to 2.71 )

1.00

1.04 (0.91 to 1.19$)$

1.66 (1.16 to 2.36 )

1.00

1.00

1.61 (1.18 to 2.20 )

3.96 (2.07 to 7.56$)$

1.00

1.18 (0.85 to 1.63$)$

0.88 (0.28 to 2.74$)$

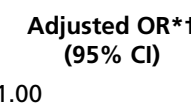

1.00

1.32 (0.65 to 2.69 )

1.00

1.04 (0.90 to 1.18)

1.60 (1.12 to 2.29 )

1.00

1.00

1.62 (1.18 to 2.22 )

3.88 (2.02 to 7.50 )

1.00

1.23 (0.88 to 1.71$)$

0.93 (0.30 to 2.94)
0.97 (0.85 to 1.11$)$

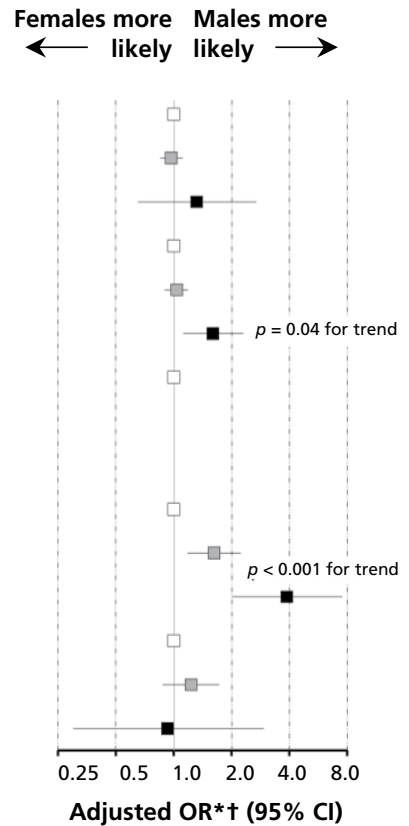

Figure 3: Crude and adjusted odds ratios (ORs) for giving birth to a male liveborn infant (index birth) among women who had abortions at $<15$ wk or $\geq 15$ wk gestation between the previous live birth and the index birth compared with women who had no abortion during the same birth interval, from 1993 to 2012, by maternal place of birth and stratified by sex of previous living sibling(s). Values greater than 1.0 indicate an increased likelihood of having a male infant. *Adjusted for maternal age and neighbourhood income quintile. $t$ Also adjusted for maternal education and marital status at arrival, and duration of residence in Canada. $¥ D$ ata were suppressed because of small counts $(\leq 5)$. $\mathrm{Cl}=$ confidence interval, $\mathrm{FF}=$ both prior living siblings were female, $\mathrm{MM}$ = both prior living siblings were male. 
can be accurately determined by ultrasonography. ${ }^{37}$ Finally, there was an average lag time of 3.8 months (i.e., $15.2 \mathrm{wk}$ ) to the birth of the third child if that child was a boy rather than a girl, which could suggest that a procedure or process had taken place during this longer interval.

In our study, prior to the live birth of a third child, one-quarter of women born in India who had previously given birth to 2 daughters underwent at least 1 induced abortion, and one-third of them underwent repeated induced abortions during that interim. These proportions likely underestimate the potential risk that a woman born in India will undergo an induced abortion after 2 daughters, because the natural probability of the next child being male is about $51 \%$, which is independent of the sex of the previous sibling(s). Multiple induced abortions have been shown to be detrimental to a woman's health and also to a subsequent pregnancy. ${ }^{38}$ In our study, we found that, among some women born in India, multiple induced abortions were performed in the short interval that elapsed between 2 consecutive live births.

Our observed male:female infant ratio of 1.96 among women born in India with 2 previous daughters is higher than the ratio that was reported in a study based on household survey data from India (male:female ratio 1.44). ${ }^{15}$ One possible explanation is that immigrants from India living in Ontario may not be representative of the population of India as a whole. Differences in study designs may be another explanation. Nevertheless, migration to Canada from India has not been accompanied by an appreciable reduction in the elevated male:female infant ratio.
Among other immigrants from Asia, there was little variation in the male:female infant ratio based on the sex of their previous children. Although women born in China who had a third child were 1.5 times more likely to have previously given birth to 2 girls rather than 2 boys, this was not correlated with a higher rate of induced abortions or skewed sex ratios in the third birth.

Determination of fetal sex by ultrasonography is $70 \%$ accurate by the 11 th week of pregnancy and $99 \%$ accurate by the 13 th week. ${ }^{37}$ In our study, births preceded by an abortion at 15 weeks or more gestation were associated with a 3-fold increase in the odds of the birth of a boy to a woman born in India who had 2 previous girls, suggesting that many abortions performed at 15 weeks or more, and some performed between 12 and 14 weeks gestation, may have been done with knowledge of the sex of the fetus. For example, second-trimester abortions were used as a proxy for sex-selective abortions in a study involving married women who had an abortion in an obstetric hospital in Vietnam. ${ }^{39}$ In a qualitative study, abortion following ultrasonography was the most common pathway used to obtain a son among immigrants from India in the United States. ${ }^{40}$

\section{Limitations}

Our study has the following limitations. First, information on the sex of the aborted fetuses was not available in our abortion records. The timing of induced abortions was dichotomized in data collection by the physician billing codes and, therefore, we could not use different cut-offs.

Table 2: Mean birth interval between second and third live births according to sex of third live birth, by maternal birthplace and sex of previous siblings

\begin{tabular}{|c|c|c|c|}
\hline \multirow[b]{2}{*}{ Sex of 2 previous siblings } & \multicolumn{2}{|c|}{$\begin{array}{c}\text { Mean birth interval between second } \\
\text { and third live births, mo }\end{array}$} & \multirow[b]{2}{*}{$\begin{array}{l}\text { Mean difference* } \\
(95 \% \mathrm{Cl})\end{array}$} \\
\hline & $\begin{array}{l}\text { Male third-born } \\
\text { infant }\end{array}$ & $\begin{array}{l}\text { Female third-born } \\
\text { infant }\end{array}$ & \\
\hline \multicolumn{4}{|l|}{ Mothers born in Canada } \\
\hline MM & 40.2 & 40.5 & $-0.2(-0.8$ to 0.3$)$ \\
\hline FF & 40.7 & 40.7 & $0.0(-0.6$ to 0.7$)$ \\
\hline MF or FM & 41.8 & 42.1 & $-0.3(-0.8$ to 0.2$)$ \\
\hline \multicolumn{4}{|l|}{ Mothers born in India } \\
\hline MM & 45.4 & 47.9 & $-2.4(-7.4$ to 2.6$)$ \\
\hline FF & 49.0 & 45.4 & $3.8(0.9$ to 6.7$) \dagger$ \\
\hline MF or FM & 47.8 & 48.8 & $-1.1(-4.6$ to 2.3$)$ \\
\hline \multicolumn{4}{|c|}{$\begin{array}{l}\text { Note: } \mathrm{Cl}=\text { confidence interval, } \mathrm{FF}=\text { both previous living siblings were female, } \mathrm{MM}=\text { both previous living siblings were male. } \\
{ }^{*} \text { Mean difference }=\text { mean birth interval to third-born male }- \text { mean birth interval to third-born female. Adjusted for the number } \\
\text { of spontaneous abortions between live births. } \\
+p=0.01 \text {. }\end{array}$} \\
\hline
\end{tabular}


Second, we may have missed some induced abortions. Data on in-hospital induced abortions can be considered complete owing to mandatory reporting, and most performed in outpatient clinics are billed by physicians under OHIP. However, induced abortions performed outside Ontario or those paid for out of pocket were not captured. Such underascertainment may have diminished the size of our observed associations by inflating the baseline male:female infant ratio (1.68) among women born in India with 2 previous daughters but no record of an induced abortion thereafter. Although the medical use of abortifacient agents, such as methotrexate, mifepristone and misoprostol, was not ascertained, this would not explain the skewed sex ratios we observed. These medications are used in about $2 \%$ of all abortions in Canada and are prescribed up to 9 weeks gestation, ${ }^{41}$ which is before fetal sex can be accurately determined. Other mechanisms may also explain the skewed male:female ratios (e.g., pre- and postimplantation determination of fetal sex). Because the use of reproductive technology to select the sex of the fetus is prohibited in Canada, ${ }^{42}$ some women may seek these services abroad. Limitations on sample size required us to collapse some countries into world regions; nonetheless, the country of birth of each immigrant was ascertained using notarized documentation submitted during the immigration application process.

Our findings may be generalized to other Canadian provinces because male-biased sex ratios are not substantially different between provinces. ${ }^{43}$ These findings may also apply to immigrants settling in other countries, as skewed sex ratios have been observed among immigrants from India in the US, United Kingdom and Norway. ${ }^{26-28,30}$ However, these findings should not be generalized to women of other ethnic origins who are not immigrants. Future studies may elucidate whether male-biased infant sex ratios are present among second-generation immigrants and whether they diminish with increasing exposure to Canadian society.

\section{Conclusion}

We found that high male:female ratios among infants of mothers born in India who immigrated to Ontario were associated with having had induced abortions, especially in the second trimester of pregnancy, when fetal sex can be accurately determined by ultrasonography. There is no simple answer to the issue of prenatal sex selection. Laws enacted to control the practice vary between ${ }^{42,44}$ and within countries. ${ }^{33}$ International agencies consider prenatal sex selection as one particular manifestation of sex discrimination against girls and women and call for the "urgent need of more-reliable data" for evidence-based policy development and action. ${ }^{45}$ Our study provides additional data that can inform the public debate on the issue.

Further research may clarify the social and cultural forces that influence some immigrant couples to have more sons than daughters, particularly in the Canadian context, which is a more sex-egalitarian society, and where the given reasons for preferring sons are supposed to be undermined..$^{10}$ The design of interventions should further consider the different voices within the affected ethnic groups, particularly those that promote women's rights and empower women to achieve their potential.

\section{References}

1. Hesketh T, Xing ZW. Abnormal sex ratios in human populations: causes and consequences. Proc Natl Acad Sci U S A 2006; 103:13271-5.

2. Jacobsen R, Moller H, Mouritsen A. Natural variation in the human sex ratio. Hum Reprod 1999;14:3120-5.

3. Rodgers JL, Doughty D. Does having boys or girls run in the family? Chance 2001;14:8-13.

4. Chahnazarian A. Determinants of the sex ratio at birth: review of recent literature. Soc Biol 1988;35:214-35.

5. James WH. Hypotheses on the stability and variation of human sex ratios at birth. $J$ Theor Biol 2012;310:183-6.

6. Markle GE. Sex ratio at birth: values, variance, and some determinants. Demography 1974;11:131-42.

7. Catalano R, Yorifuji T, Kawachi I. Natural selection in utero: evidence from the Great East Japan Earthquake. Am J Hum Biol 2013;25:555-9.

8. James WH. The variations of human sex ratio at birth during and after wars, and their potential explanations. J Theor Biol 2009;257:116-23.

9. Scherb H, Kusmierz R, Voigt K. Increased sex ratio in Russia and Cuba after Chernobyl: a radiological hypothesis. Environ Health 2013;12:63.

10. Almond D, Edlund L, Milligan K. Son preference and the persistence of culture: evidence from South and East Asian immigrants to Canada. Popul Dev Rev 2013;39:75-95.

11. Sev'er A. Discarded daughters: the patriarchal grip, dowry deaths, sex ratio imbalances \& foeticide in India. Womens Health Urban Life 2008;7:56-75.

12. Committee on Ethics, American College of Obstetricians and Gynecologists. ACOG Committee opinion No. 360: sex selection. Obstet Gynecol 2007;109:475-8.

13. Hull TH. Recent trends in sex ratios at birth in China. Popul Dev Rev 1990;16:63-83.

14. Sen A. Missing women - revisited. BMJ 2003;327:1297-8.

15. Jha P, Kumar R, Vasa P, et al. Low female[corrected]-to-male [corrected] sex ratio of children born in India: national survey of 1.1 million households [published erratum in Lancet 2006;367:1730] Lancet 2006;367:211-8.

16. Jha P, Kesler MA, Kumar R, et al. Trends in selective abortions of girls in India: analysis of nationally representative birth histories from 1990 to 2005 and census data from 1991 to 2011. Lancet 2011;377:1921-8

17. Sen A. Missing women. BMJ 1992;304:587-8.

18. Löfstedt P, Shusheng L, Johansson A. Abortion patterns and reported sex ratios at birth in rural Yunnan, China. Reprod Health Matters 2004;12:86-95.

19. Zhu WX, Lu L, Hesketh T. China's excess males, sex selective abortion, and one child policy: analysis of data from 2005 national intercensus survey. BMJ 2009;338:b1211.

20. Chatterjee P. Sex ratio imbalance worsens in Vietnam. Lancet 2009;374:1410

21. Guilmoto CZ, Hoang X, Van TN. Recent increase in sex ratio at birth in Viet Nam. PLOS ONE 2009;4:e4624.

22. Hesketh T, Lu L, Xing ZW. The consequences of son preference and sex-selective abortion in China and other Asian countries. CMAJ 2011;183:1374-7. 
23. Lamichhane P, Harken T, Puri M, et al. Sex-selective abortion in Nepal: a qualitative study of health workers' perspectives. Womens Health Issues 2011;21(Suppl):S37-41.

24. Larsen U, Chung W, Das Gupta M. Fertility and son preference in Korea. Popul Stud (Cam) 1998;52:317-25.

25. Lee IW, Lai YC, Kuo PL, et al. Human sex ratio at amniocentesis and at birth in Taiwan. Taiwan J Obstet Gynecol 2012; 51:572-5.

26. Abrebaya J. Are there missing girls in the United States? Evidence from birth data. Am Econ J Appl Econ 2009;1:1-34.

27. Almond D, Edlund L. Son-biased sex ratios in the 2000 United States Census. Proc Natl Acad Sci U S A 2008;105:5681-2.

28. Dubuc S, Coleman D. An increase in the sex ratio of births to India-born mothers in England and Wales: evidence of sexselective abortion. Popul Dev Rev 2007;33:383-400.

29. Ray JG, Henry DA, Urquia ML. Sex ratios among Canadian liveborn infants of mothers from different countries. CMAJ 2012;184:E492-6

30. Singh N, Pripp AH, Brekke T, et al. Different sex ratios of children born to Indian and Pakistani immigrants in Norway. BMC Pregnancy Childbirth 2010;10:40.

31. UNFPA guidance note on prenatal sex selection. New York: United Nations Population Fund; 2014. Available: www.unfpa.org/ sites/default/files/resource-pdf/guidenote_prenatal_sexselection.pdf (accessed 2015 Oct. 3).

32. Birth ratios in England and Wales. A report on the gender ratios at birth in England and Wales. London: Department of Health; 2014. Available: www.gov.uk/government/uploads/system/ uploads/attachment data/file/313559/Sex Selection in England and_Wales_analysis_April_2014_NM_comments.pdf (accessed 2015 Oct. 3).

33. Citro B, Gilson J, Kalantry S, et al. Replacing myths with facts: sex-selective abortion laws in the United States. Ithaca (NY): Cornell University Law School; 2014.

34. Smith C, Fogarty A. Is the mothers' country of birth associated with the sex of their offspring in England and Wales from 2007 to 2011? BMC Pregnancy Childbirth 2014;14:332.

35. Arnold F. Measuring the effect of sex preference on fertility: the case of Korea. Demography 1985;22:280-8.

36. Urquia ML, Frank JW, Moineddin R, et al. Does time since immigration modify neighborhood deprivation gradients in preterm birth? A multilevel analysis. J Urban Health 2011; 88:959-76.

37. Efrat Z, Akinfenwa OO, Nicolaides KH. First-trimester determination of fetal gender by ultrasound. Ultrasound Obstet Gynecol 1999; 13:305-7.

38. Oliver-Williams C, Fleming M, Monteath K, et al. Changes in association between previous therapeutic abortion and preterm birth in Scotland, 1980 to 2008: a historical cohort study. PLoS Med 2013;10:e1001481.

39. Bélanger D, Oanh KT. Second-trimester abortions and sexselection of children in Hanoi, Vietnam. Popul Stud (Camb) 2009;63:163-71.

40. Puri S, Adams V, Ivey S, et al. "There is such a thing as too many daughters, but not too many sons": a qualitative study of son preference and fetal sex selection among Indian immigrants in the United States. Soc Sci Med 2011;72:1169-76.

41. Erdman JN, Grenon A, Harrison-Wilson L. Medication abortion in Canada: a right-to-health perspective. Am J Public Health 2008;98:1764-9.

42. The Law Library of Congress. Sex selection and abortion: Australia, Canada, India, and New Zealand. Washington (DC): The Law Library of Congress, Global Legal Research Center; 2009. Available: http://loc.gov/law/help/sex-selection/index.php (accessed 2015 May 1).

43. Urquia ML, Ray JG, Wanigaratne S, et al. Variations in malefemale ratios among births to Canadian-and Indian-born mothers, 1990-2011: a population-based register study. CMAJ Open 2016; 4(2):E116-23.

44. Webb DC. The sex selection debate: a comparative study of sex selection laws in the United States and the United Kingdom. South Carolina J Int Law Bus 2014;10:163-200.

45. Preventing gender-biased sex selection. An interagency statement OHCHR, UNFPA, UNICEF, UN Women and WHO. Geneva: World Health Organization; 2011.

Affiliations: Centre for Global Health Research (Jha), St. Michael's Hospital; Centre for Research on Inner City Health (Urquia, O'Campo, Glazier), Li Ka Shing Knowledge Institute, St. Michael's Hospital; Departments of Medicine, and Obstetrics and Gynecology (Ray), St. Michael's Hospital; Dalla Lana School of Public Health (Urquia, Jha, O'Campo, Henry), University of Toronto; Department of Family and Community Medicine (Moineddin, Glazier), University of Toronto; Centre for Addiction and Mental Health (McKenzie), University of Toronto; Department of Psychiatry (McKenzie), University of Toronto; Institute for Clinical Evaluative Sciences (Urquia, Moineddin, O'Campo, Glazier, Henry, Ray), Toronto, Ont.

Contributors: Marcelo Urquia conceived the study and acquired the data. Marcelo Urquia and Rahim Moineddin analyzed the data. Marcelo Urquia wrote the paper in collaboration with Joel Ray, with input from all of the authors. All of the authors contributed to the study design, interpreted the results, critically reviewed the manuscript for intellectual content, gave final approval for the version to be published and agreed to act as guarantors of the work.

Funding: The study was funded by a grant from the Canadian Institutes of Health Research (CIHR). Marcelo Urquia holds a CIHR New Investigator Award. Prabhat Jha is supported by a University of Toronto Endowed Chair and a Canada Research Chair. Richard Glazier is supported as a Clinician Scientist in the Department of Family and Community Medicine at the University of Toronto and St. Michael's Hospital. Joel Ray holds a CIHR Chair in Reproductive, Child and Youth Health Services and Policy Research.

Acknowledgments: The study was possible thanks to the Institute for Clinical Evaluative Sciences (ICES), which is supported by an annual grant from the Ontario Ministry of Health and Long-Term Care. The opinions, results and conclusions reported in this article are those of the authors and are independent from the funding sources. No endorsement by ICES or the Ontario Ministry of Health and Long-Term Care is intended or should be inferred. Parts of this material are based on data and information compiled and provided by the Canadian Institute for Health Information (CIHI). However, the analyses, conclusions, opinions and statements expressed herein are those of the authors, and not necessarily those of CIHI. The authors would also like to thank Kripa Sekhar (South Asian Women's Centre), Neethan Shan (Council of Agencies Serving South Asians), Baldev Mutta (Punjabi Community Health Services) and Rabindra Sabat (Settlement Assistance and Family Support Services) for their input to this study. No endorsement by these individuals or their organizations should be inferred. 